\title{
Metadiscourse in Business English: Ideas for the EBC Class
}

\author{
M. Antonietta Marongiu ${ }^{1}$ \\ ${ }^{1}$ Faculty of Economic, Legal and Political Sciences, University of Cagliari, Italy \\ Correspondence: M. Antonietta Marongiu, Faculty of Economic, Legal and Political Sciences -Via Sant'Ignazio, \\ 78, 09123 Cagliari, Italy. E-mail: marongiuma@unica.it
}

Received: April 26, $2021 \quad$ Accepted: July 8, $2021 \quad$ Online Published: July 14, 2021
doi:10.5539/ijel.v11n5p1

\begin{abstract}
Metadiscourse has been defined as the discourse used by writers to help their readers connect, interpret and evaluate their attitudes towards the referential material presented (Vande Kopple, 2002). In his study on CEO's letters, Hyland (1998b) examined metadiscourse as the manifestation of a writer's linguistic and rhetorical presence in the text and looked at the persuasive nature of business communication. An awareness of the rhetorical power of metadiscourse in this text genre is vital for professional development, particularly in the teaching of business English. This study was designed to examine the use of interactive and interactional metadiscourse in Business English writing through an analysis of the Enron Email Dataset and the Business Letter Corpus. The data analysis was conducted following Hyland $(2005,2019)$, in order to understand how content and discourse are set up to orient and persuade the reader. Although this study focuses specifically on interactional metadiscourse, the results are expected to be relevant for the ESP classroom, particularly in English for Business Communication (EBC) classes (Bhatia \& Bremner, 2012). Acquiring conscious awareness of the rules and conventions to master formal writing can be of great help to business students in order for them to become successful writers in both academic and professional environments.
\end{abstract}

Keywords: discourse analysis, metadiscourse, corpus linguistics, English for business communication

\section{Introduction}

A wealth of research has shown the relevance of metadiscourse in creating persuasive and argumentative discourse, and in fulfilling rhetorical functions in written text production. Metadiscourse has been recognized as an important tool to facilitate communication, to support a writer's stand, increase readability and build a relationship with an audience (Hyland, 2005, p. 5). Thus, this work will provide an analysis of corporate emails and business letters to see what interactional metadiscoursal resources are used and what rhetorical functions they perform.

The corpora scrutinized were produced in English-speaking corporate contexts, for business communication purposes. Being products of the business English professional community, it was expected that an analysis thereof would provide insightful considerations for the teaching of English for Business Communication (EBC). As a matter of fact, the use of metadiscourse was found to depend on the contexts and values of those who enact it and of their audience; thus, it is coherent with the norms and expectations of particular cultural and professional communities (Hyland, 1998b, p. 438). The underlying tenet hereafter is that providing adequate input about metadiscourse and occasions to use it productively in the EBC class can help students to become more aware and more skilled writers in their professional community. The relevance of studying how metadiscourse is used in business English texts becomes clearer when considering that EBC students have different cultural and linguistic backgrounds and might have different definitions of politeness and face (Vande Kopple, 2002, p. 108).

The shift to digitalized business communication in the late '90s/early 2000s has favoured the use of the email in internal and external business exchanges (cf. Hewitt, 2006; Evans, 2012). Communication has become more flexible, yet, while corporate emails and business letters may be used for the same purposes, they remain two different text genres. The email does not seem to have a pre-established frame of reference and agreed-upon structure (Hu, Wong, Cheah, \& Philip, 2009; Evans, 2012). However, emails tend to be more concise texts in length, language and structure, than are letters; therefore, the linguistic choices available to authors to create propositional content as well as interpersonal engagement may be more limited. 
Drawing upon these considerations, the transcripts of corporate emails and business letters taken into account in this work have been analysed according to Hyland's $(2005$, p. 48) interpersonal model of metadiscourse, to see what interactional resources writers adopt to manifest their attitudes towards the content and the reader. Metadiscoursal resources have been examined within their context to see whether or not they are used as persuasive strategies by making credible (Ethos), affective (Pathos) and rational (Logos) appeals to the readers. Although an examination of interactive metadiscourse strategies is part of this on-going project, they are not part of the scope of this study.

This paper will first offer a short discussion on the theoretical framework underlying this research (Section 2). The objectives of the research will be mapped out together with the data under scrutiny and the methodological approach adopted for data analysis (Section 3). The discussion of quantitative and qualitative findings will be complemented by an analysis of the examples taken from the transcripts of the original data set (Section 4). Before drawing final conclusions, the pedagogical implications of introducing metadiscourse to fulfil rhetorical functions in the EBC class will be given some consideration (Section 5).

\section{Theoretical framework}

\subsection{Metadiscourse}

Studies on metadiscourse have been carried out in the fields of discourse analysis, pragmatics and language teaching (among others), and have become one of the most commonly explored features of specialist written texts. Metadiscourse analysis has largely focused on specialized language, rather than general conversational competencies. More specifically, it refers to the commentaries the writer or speaker employs to help the reader/listener to interpret and evaluate attitudes towards the propositional material of a text (Crismore, 1989; Vande Kopple, 1985, 2002, 2012). Indeed, communication is not just an exchange of information, goods or services; people employ metadiscourse to share their attitudes towards the content and transmit their assumptions about their interlocutors (Hyland, 2000, 2005).

Scholars have not agreed on the classification of metadiscourse, or on the research methodology to adopt. Metadiscourse is context-dependent, culture and language related, genre-governed and subject to individual interpretation. The first classification was made by Vande Kopple (1985), who referred to a level of discourse where metadiscourse commentaries serve to clarify either the interpersonal or the textual meaning.

Hyland (2005) proposed an interactive model of metadiscourse identifying interactive and interpersonal strategies. As communication is a social event, metadiscourse shows the writer's awareness of the reader's presence, and their ability to clarify and guide the interaction, and in general to understand the community being addressed (cf. Hyland \& Tse, 2004; Hyland, 2017). Thus, the use of metadiscourse has to do with the conventions developed through participation in common situations, where interests and meanings are shared.

More focused on textual metadiscourse is the approach adopted by Mauranen (1993) and later by Ädel (2006). The latter developed a taxonomy of metadiscourse based on the concept of text reflexivity. Arguing in favour of a strictly context and language-related interpretation of metadiscourse, she rejected corpus-based or quantitative approaches to research, or the use of pre-established sets of lexical items for the analysis of texts produced in different languages (Ädel, 2010, 2012; Ädel \& Mauranen, 2010). Ädel's taxonomy of metadiscourse and her methodology have been applied to both spoken and written academic English (Salas, 2015; Zhang, 2016).

Scholars have largely focused on specialized English text production in academic contexts, to study postgraduate dissertations (Hyland \& Tse, 2004), research articles in various disciplines (Hyland, 1998a, 2001; Reitbauer, 2001; Estaji \& Vafaeimehr, 2015; Hyland \& Jiang, 2018), undergraduate textbooks (Hyland, 2000) and even school textbooks (Crismore, 1989). Some interest in academic writing has been oriented specifically to the use of metadiscourse to engage the reader, to signal co-membership and disciplinary in-group belonging (Hyland, 2017; Biber, 2006). Research has also been devoted to spoken production, such as in academic lectures (Ädel, 2012; Àgnes, 2012; Lee \& Subtirelu, 2015; Zhang, Sun, Peng, Gan, \& Yu, 2017), and in digitalized discourse (Ryoo, 2005; Giordano \& Marongiu, 2020).

Investigations over the past few decades have looked into texts of diverse genres (Vashegani Farahani \& Abdallah Mohemmed, 2018) especially produced in English as L1 and L2 by authors with different linguistic backgrounds (Ädel, 2006; Hong \& Cao, 2014; Vashegani Farahani \& Sabetifard, 2017) as well as texts produced in English and in other languages, such as Chinese (Hu \& Cao, 2011), Finnish (Mauranen, 1993), Yemeni (Al Mudhaffari, Hussin, \& Abdullah, 2020), Persian (Abdollahzadeh, 2011; Attarn, 2014), and Spanish (Salas, 2015). This research has confirmed that metadiscourse in text writing may vary depending on the language and culture and that the differences in the conventions adopted may spring from varying ideas of politeness and of 
writer/reader relationships (Crismore, Markkanen, \& Steffersen, 1993; Mauranen, 1993; Akbas \& Hatipoğlu, 2018).

\subsection{Pedagogical Relevance of Metadiscourse in the L2 Classroom}

The question of how to teach metadiscourse has been raised in rhetoric and composition classes as well as in second/foreign language instruction. In the field of language learning, primarily with regards to English as a second/foreign language, metadiscourse has been examined in order to probe its relevance as a pragmatic tool per se and in text production and comprehension in general (Crismore, 1990; Crismore \& Vande Kopple, 1997; Crawford Camiciottoli, 2003; Hyland, 2004; Amiryousefi \& Rasekh, 2010; Tavakoli, Dabaghi, \& Khorvash, 2010; Ahour \& Entezari Maleki, 2014; Chang, 2015).

Moreover, the introduction of the conventions governing metadiscourse in the teaching of text production was found to be beneficial to the improvement of students' writing skills (Fatalaki, Amini, \& Mirzaee, 2014; Vashegani Farahani \& Pahlevansadegh, 2018) as well as their speaking skills (Hour \& Maleki, 2014).

Metadiscourse is also crucial to help students understand the notion of tone in order to learn to amend it in their own writing. It can guide them in refining their own ethical sensibilities through the comparison of positive examples with other clear examples of misuse, of manipulatory and mischievous use of metadiscourse. Introducing metadiscourse in the EBC classroom can help students to better evaluate the truthfulness and validity of the information at hand both as readers and as writers (Vande Kopple, 2002).

\subsection{Metadiscourse in Business Writing}

Metadiscourse in business genres is a somewhat under-represented topic of research in spite of the significant role that rhetoric and persuasion have in business communication. One of the most interesting works in this direction is still Hyland's (1998b) study on the use of metadiscourse in CEOs' letters to shareholders, in which he drew attention to the relevance of metadiscourse as a key component of corporate rhetoric. Widely viewed as a promotional text genre, CEO's letters seek to build corporate credibility and persuade investors through the effective use of rhetoric. Similar conclusions were reached in a more recent study on metadiscourse in American and Chinese corporate letters written in English to shareholders (Xiaoqin, 2017). In these particular corpora, interactional metadiscourse is used to accomplish rhetorical and persuasive goals, though it seemed to occur with higher frequency in the American-letters corpus. Likewise, the comparison of Chinese English and Western English corpora in CEO letters from banking annual reports confirmed they both used metadiscourse to build rhetorical appeal. Any meaningful variation in the type of appeal was credited to the interplay of cultural and linguistic differences (Huang \& Rose, 2018).

With the gradual shift of business activities into cyberspace, research has begun to investigate the use of metadiscourse in business emails written by native and non-native speakers of English (Kankaanrantan, 2006; Jensen, 2009; Ehrenreich, 2010; Carrio-Pastor \& Muñiz Calderón, 2015; Carrio-Pastor, 2019).

\section{Data and Methodology}

The purpose of this study is to ascertain how metadiscourse is used as a means of persuasion and a rhetorical strategy in corporate emails and business letters, which are an essential means of communication in the business community. By adopting Hyland's interpersonal model of metadiscourse (2005, p. 49) classification of metadiscourse in academic writing for the analysis of business texts, it will be of interest for this research to examine: (a) what metadiscourse features or strategies are most commonly used in business emails and letters; (b) whether there are meaningful differences between the two text genres in the use of the same strategies; (c) and what function(s) they actually fulfil. Furthermore, an analysis of results should offer some reality-based contribution to the teaching of EBC.

Based on a functional approach, Hyland's model distinguishes between two dimensions of metadiscourse "to acknowledge the organizational and evaluative features of interaction." (Hyland, 2001, 2005; Hyland \& Tse, 2004). The interactive dimension focuses on the writer's assumptions about the audience, on how the author seeks to accommodate the content to the audience's rhetorical expectations and presumed processing abilities. The interactional dimension, on the other hand, concerns "the writer's expression of a textual 'voice', or community-recognized personality", including judgements and explicit alignments with the reader (Hyland, 2005, p. 49). Hyland himself mentions the limits such a model can have, since: "A classification scheme can [...] only approximate the complexity of natural language use." (Hyland, 2005, p. 59). Accordingly, studies on metadiscourse can dissect the explicit devices, i.e., the surface features the author chooses to use in a text. Yet, metadiscourse must be analysed from a functional perspective, that is by taking into account the surrounding co-text and the author's intended goals in creating the text. 
Hyland's 2005 model of metadiscourse provides a non-exhaustive list of items considered that can fulfil the functions classified (Note 1). The items in this list have been taken into consideration for the analysis of the corpora used for this on-going research. Although both interactive and interactional dimensions of metadiscourse have been examined, due to space constraints, this discussion will only focus on interactional metadiscourse.

In this study, two corpora were taken into consideration and partially analysed as productions of a specific discourse community. The first one, the Enron Email Dataset (henceforth EED) is a database of about 0.5M email messages generated by 150 employees, mostly senior management, of the Enron Corporation in the years leading up to the company's collapse in December 2001. The currently downloadable dataset, only partially cleaned of metadata, repetitions, attachments and sensitive data, was made available for research by the University of Massachusetts. This corpus is considered the only substantial collection of "real" emails that is public. Access to other datasets is restricted due to privacy concerns. This is the May 7, 2015 Version of the dataset (about $1.7 \mathrm{~Gb}$, tarred and zipped, available at www.enron-mail.com and at www.cs.cmu.edu/ enron/).

The second corpus used is the Business Letter Corpus (henceforth BLC), which contains over 11thousand business-related documents, 1,020,060 words of U.S. and U.K. samples, covering a wide spectrum of day-to-day business communication scenarios such as inquiries, requests, refusals, apologies, complaints, claims, reminders, confirmations, invitations, negotiations, order processing, sales promotions, business proposals, customer relations, seasonal greetings, as well as other kinds of interoffice correspondence. Originally written in the form of business letters, memorandums and other business-related documents dated April 1997 through March 1998, this version of the corpus was compiled by Yasumasa Someya as BusinessLetterCorpus.txt, made available for corpus research through Online KWIC Concordancer at www.someya-net.com/concordancer/.

A quantitative analysis of the corpora's transcripts was carried out using two different corpus managers. Sketch Engine was used for the EEC (Figure 1), while the Online KWIC Concordancer, where the corpus is uploaded, was used for the scrutiny of the $B L D$ (Figure 2).

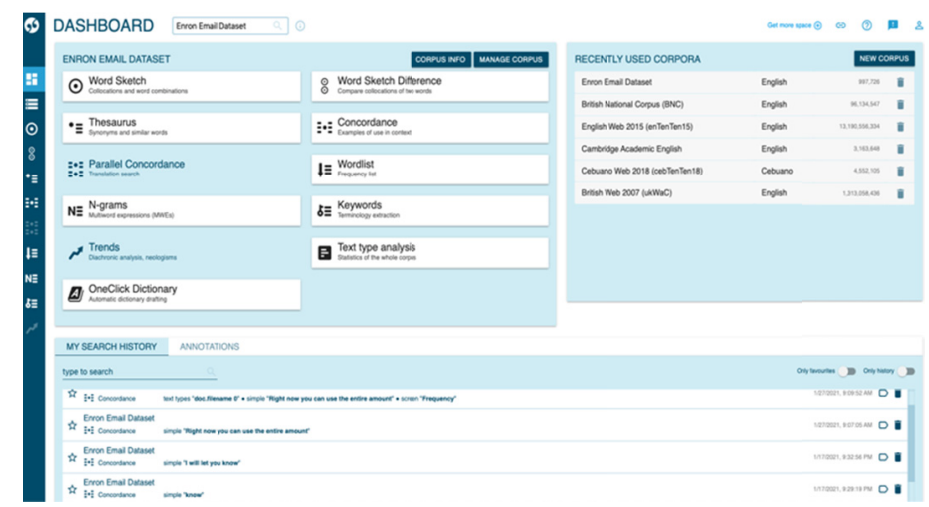

Figure 1. Dashboard of the corpus manager Sketch Engine used to analyse the Enron Email Corpus

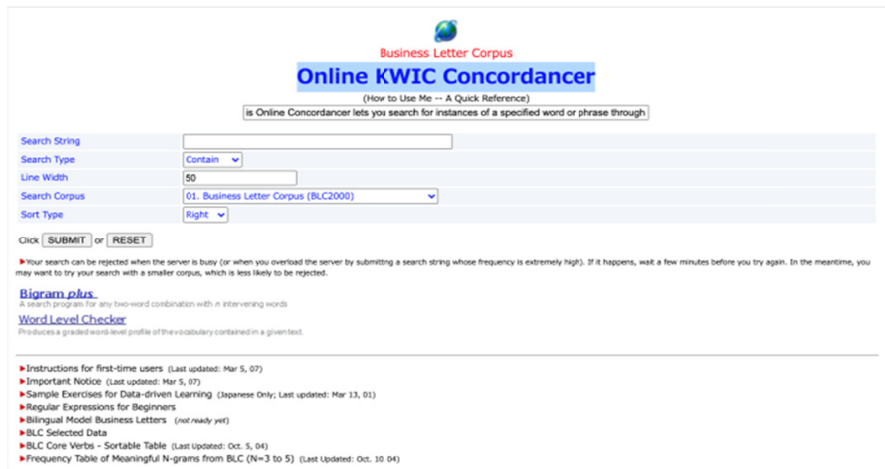

Figure 2. Dashboard of the corpus manager Online KWIC Concordancer where the Business Letter Dataset is uploaded (www.cs.cmu.edu/ enron/) 
Given the extent of the EED corpus in comparison to the BLD's, for the purposes of this investigation a sub-set of "sent" emails of about 1M words was selected from the EED in order to match the size of the BLC. Both corpora include inquiries, requests, refusals, apologies, complaints, claims, reminders, confirmations, invitations, negotiations, order processing, sales promotions, business proposals, customer relations, seasonal greetings, as well as other various kinds of interoffice correspondence. As shown in Table 1, the "sent-mail" sub-set of the EED includes 4,219 documents in 280 archived files, 1,527,938 tokens, 997,726 words, 37,221 sentences. The $B L C$ is collected in 34 archived files with 10,587 documents, 65,338 sentences, 1,020,060 words and 1,114,018 tokens.

Table 1. Specifications regarding the two corpora under investigation: the "sent-email" sub-set from the Enron Email Dataset and the Business Letter Corpus

\begin{tabular}{lll}
\hline Specifications & $\begin{array}{l}\text { Sent mail } \\
\text { sub-set of EED }\end{array}$ & BLC \\
\hline Tokens & 1527938 & 1114018 \\
Words & 997726 & 1020060 \\
Sentences & 37221 & 65338 \\
Documents & 280 & 34 \\
Archived files & 4219 & 10587 \\
\hline
\end{tabular}

The quantitative investigation entailed a digital search of the items listed in Hyland's framework; however, the results of this inquiry proved to be unsatisfactory, owing to the size of the corpora. In order to establish whether an item is acting on a metadiscoursal level, it needs to be analysed within its discourse context. Therefore, the occurrences baring statistical relevance were sampled out and examined manually within their concordance line, to determine whether or not they were fulfilling a metadiscoursal function. The following section is a discussion of some of the findings with relevant examples.

\section{Analysis and Discussion}

According to Hyland (2005, p. 52), the interactional dimension of metadiscourse can be identified by looking at a writer's presence in the interaction and the commentaries to their own message. At this level, the writer communicates her/his attitudes towards both the propositional information and the readers, and guides readers in the interpretation of the content by means of persuasion. In his model, Hyland classified hedges, boosters, attitude markers, self-mentions, and engagement markers. However, these discrete categories are not to be found in isolation in language use, given the polypragmatic character of discourse. Different metadiscoursal categories may be traced simultaneously, as writers seek to accomplish a variety of concurrent/concomitant objectives; in their attempts to be persuasive, they rely on all their rhetorical resources.

Analysis of the corpora revealed that, among the interactional metadiscourse strategies classified in Hyland's model of reference, attitude markers were fairly infrequent. The only items that were found to occur in any noteworthy quantity (cases in hundreds) were 'agree' (169 in the EED and 252 in the BLC), 'even' (234 in the EED and 350 in the BLC), 'appropriate' (107 in the EED and 179 in the BLC), and 'important' and 'unfortunately' only in the BLC (respectively 300 and 255). Attitude markers reveal the writer's emotional attitudes towards both propositional content and the reader's putative stand-point. The lack of attitude markers in emails was not surprising, given that they tend to be brief and are often used for straightforward communication. Contrariwise, they were expected to appear more frequently in business letters, where writers strive to create an active and engaging dialogue with their interlocutors and to look at the matter from the readers' perspective, possibly inviting them to respond. Unlike other interactional metadiscourse strategies, attitude markers create affective appeal and can directly emphasise the writer's sympathetic attitude to the reader's values, even when the letter content may be a rejection of a request. They can therefore be very effective in business communication.

The interactional metadiscourse features that proved to be statistically the most relevant in the corpora scrutinised are the self-mentions ' $I$ ' and 'we' and the engagement markers 'you' and 'your'. A writer's presence in the text is first and foremost revealed through self-mentions, which serve to demonstrate their credibility and to build their rhetorical identity (Hyland, 2001). Self-mention markers show how the author is committed to the content and to the establishment of a relationship with the reader. As expected, Table 2 shows a relatively higher occurrence of the first-person singular subject pronoun ' $I$ ', compared to other self-mentions. This was evident in both the EED and the BLC, while the presence of the first-person plural pronoun 'we' was more frequent in the 
BLC. Other pronouns and possessive adjectives are statistically less frequent, appearing merely in tens in both corpora. The weight of an author's presence in a text has proven to trigger solidarity with the interlocutors, something which is especially important in business communication, for marketing goods and services, and to consolidate customer trust (Fuentes Oliveira, Velasco Sacristán, \& Arribas Baño, 2001). In corporate internal communication it also creates bonds and forges a sense of belonging among employees.

Table 2. Self-mentions reveal the presence of the writer in the text

\begin{tabular}{lllll}
\hline SELF-MENTIONS & \multicolumn{3}{l}{ EED } & \multicolumn{3}{l}{ BLC } \\
\cline { 2 - 5 } & $\#$ & $\%$ & 15689 & 1.54 \\
\hline$I$ & 13420 & 1.34 & 3525 & 0.34 \\
me & 3572 & 0.36 & 3810 & 0.37 \\
my & 2389 & 0.24 & 15717 & 1.54 \\
we & 4765 & 0.48 & 10126 & 0.99 \\
our & 1328 & 0.13 & 3791 & 0.37 \\
us & 743 & 0.07 & & \\
\hline
\end{tabular}

In the letter sample in (1), the writer replies to a previous customer's request letter by disassociating herself from the responsibility of giving further information, however, she commits to forwarding the request to someone who can deal with it. The use of the personal pronoun ' $I$ ' signals the writer's personal involvement in assisting the customer. The following sample (2) comes from a cover letter for a job application; it shows the use of self-mention markers together with other features of interactional metadiscourse. The writer's strong persuasive presence emerges especially in the combination of the personal pronoun ' $I$ ' with verbs indicating emotion ('I am happy' and 'I feel') and personal will ('I would like to'), both classifiable as boosters. In this example, the speaker is building professional credibility by indirectly referring to a deserved promotion and to her desire for upward career mobility.

(1) "I have passed on your request for more information" [BLC2:01:00386]

(2) "Although $I$ am happy here, $I$ feel that $m y$ promotion prospects are limited, and $I$ would like to move to a better job." [BLC2:01:00560]

Self-mentions often contrast with engagement markers, as the previous examples show. With engagement markers, writers explicitly address the readers to include them as discourse participants or to downplay their presence in the text. Of all engagement markers listed in Hyland's 2005 Appendix, Table 3 shows those most frequently used in the EED and in the BLC. The personal pronoun 'you' is the engagement marker with the highest presence in both corpora. Another marker with a significant presence, especially in the BLC, is 'your'. The other engagement markers that were found to have some relevance in the corpora are the imperative forms of the verbs ' $g o$ ', 'let', and 'see', some occurrences of which are courtesy formulas. Contrary to what was/might be expected, modal verb forms occur only occasionally in the corpora.

Table 3. Engagement markers explicitly addressing the readers

\begin{tabular}{lllll}
\hline ENGAGEMENT MARKERS & EED & \multicolumn{3}{l}{ BLC } \\
\cline { 2 - 5 } & $\#$ & $\%$ & $\#$ & $\%$ \\
\hline go & 2259 & 0.23 & 668 & 0.06 \\
Let(s)/me/us & 1880 & 0.19 & 2179 & 0.21 \\
need & 1355 & 0.13 & 920 & 0.09 \\
See/saw/seen/seeing & 1477 & 0.15 & 1225 & 0.12 \\
you & 11605 & 1.16 & 25582 & 2.51 \\
your & 3767 & 0.38 & 15965 & 1.56 \\
Our & 1328 & 0.13 & 10126 & 0.99 \\
\hline
\end{tabular}

Like self-mentions, engagement markers are used together with other interactional features of metadiscourse, as is shown in the excerpts below. Sample (3) comes from a letter where the company's representative replies to a loyal customer. The writer brings the interaction to a personal level by making it a 'you'-and-' $I$ ' matter, and reinforces an appeal to emotions by addressing the reader with the booster 'can be sure'. Commitment to a personal role and position is shown in (4), an extract from the BLC, where the writer reassures the interlocutor by addressing her directly, and builds professional credibility by offering help and answers to possible questions 
the reader may want to ask.

A quite different example of the use of engagement markers is in (5), an email where instructions are provided in the imperative form, including the negative request ' $d o$ not extend ...' which marks the power imbalance between writer and reader, albeit introduced by a polite 'please'. The email develops the interactional dimension though the interrelation of the self-mention ' $I$ ' and the engagement markers 'you' and 'your', with which the writer rhetorically positions the reader, predicting possible objections and guiding her to a particular interpretation (Hyland, 2005, p. 54).

(3) "You can be sure $I$ 'll continue to justify the faith you have put in ..." [BLC2:01:00076]

(4) "If there is anything else we can help you with, I'm sure Mr (NAME) will have the answers you seek." [BLC2:01:00410]

(5) "Please confirm your attendance for the two days with [NAME] at [NUMBER] by January 29th 5:00p.m. If you are unable to attend, it may be appropriate to select someone else to participate. Please do not extend an invitation to anyone else to take your place until you and $I$ have discussed this. $I$ thank you in advance for your participation and look forward to seeing you in Dallas! [EED doc\#279 FileName: beck-s.nsf]

Writers use hedges to indicate their own stance, while at the same time allowing for alternative voices. Hyland (1998b, p. 231), found hedges to be the most frequently used interactional commentary in CEO company reports. Yet, despite searching all the hedges listed in Hyland's model, they do not seem to be used with any significant frequency in the corpora under scrutiny, especially in the EED. The most frequent hedges are realised using modal verbs. Modality indicates degrees of confidence, but also of prudence and caution, in expressing authority in a certain area of knowledge. As Table 4 shows, the modal verbs 'can' and 'would' are the most frequently used modals in both corpora, and the presence of 'would' is almost double in the BLC compared to the EED.

Table 4. Modal verbs functioning as hedges in the EED and in the BLC

\begin{tabular}{lllll}
\hline MODAL VERBS & \multicolumn{2}{l}{ EED } & \multicolumn{2}{l}{ BLC } \\
\cline { 2 - 5 } & $\#$ & $\%$ & $\#$ & $\%$ \\
\hline Can & 2613 & 0.26 & 3580 & 0.35 \\
Could/couldn't/could not & 865 & 0.09 & 981 & 0.10 \\
May & 950 & 0.09 & 1818 & 0.18 \\
Might & 351 & 0.03 & 421 & 0.04 \\
Should/Should not/shouldn't & 877 & 0.09 & 1336 & 0.13 \\
would ('d)/would not/wouldn't & 2628 & 0.26 & 4314 & 0.42 \\
\hline
\end{tabular}

As shown in Table 5, besides the modal verbs, there are very few other instances of hedges. Regarding adverbs, it may be worth mentioning the use of 'about', especially in the BLC, and of 'probably', especially in the EED, to moderate an assertion. The string 'I think', possibly used to introduce information as a personal opinion, to mitigate instructions, or to show openness to negotiation, is used more in the emails than in the business letters, since emails tend to be more personal and informal. On the other hand, more formal expressions, such as 'from my perspective' or 'in my opinion' or 'to my knowledge', listed in Hyland's 2005 Appendix, are not used at all in either corpus while they were expected to be found in the BLC in particular.

Table 5. Hedges serve to mitigate the strength of a statement, and present information as a personal opinion

\begin{tabular}{lllll}
\hline HEDGES & EED & \multicolumn{3}{l}{ BLC } \\
\cline { 2 - 5 } & $\#$ & $\%$ & $\#$ & $\%$ \\
\hline about & 1602 & 0.16 & 2048 & 0.20 \\
probably & 367 & 0.04 & 125 & 0.01 \\
Ithink/thought & 793 & 0.08 & 333 & 0.03 \\
Seem/s/ed & 414 & 0.04 & 225 & 0.02 \\
\hline
\end{tabular}

The letter sample in (6) shows the presence of the modal verb 'would' within the idiomatic structure 'we'd like you to' and of the adverb 'about', both used to mitigate the request that is being made to the interlocutor. On the other hand, (7) is part of an email where the writer, as organizer, presents the provisional plans for an important business convention. Unlike in the previous excerpt, here the use of the conditional form 'should be' strengthens 
the writer's professional choices. Yet this strong statement is immediately weakened by the presence of the adverb 'about' referring to the time of the video to be viewed, which altogether shows that not everything has been decided yet, and indirectly calls for approval.

In the following extracts, the clause 'I think' is used in combination with modal verbs. In the letter sample (8) the writer offers professional expertise to make improvements, but at the same time expresses strong criticism of the state of the art. Sample (9) is part of an email where a higher-ranking manager assigns a newly employed member of staff to a lower-ranking manager for training purposes. The use of the modal 'can' and of the conditional 'could' in combination with the strings 'I thought/I think' transforms the directives into apparent suggestions supposedly opening the writer's position to discussion and negotiation. The information regarding the decision taken at higher levels is presented as a personal opinion and even as an appreciation of the interlocutor's skills. In so doing, the writer is appealing simultaneously to Logos and Pathos.

(6) "Also, we'd like you to allow about 15 minutes at the end of your talk for audience questions" [BLC2:09:08420]

(7) "The purpose of this video is to provide a comic interlude to the proceedings. The videos will be seen prior to the dinner on Friday night at Saddleridge. The video should be about 5 minutes in length, on a VHS tape and is a zero budget assigned to the production of the video." [EEDdoc\#40-Filename: sent-items_allenp]

(8) "I think I can identify some areas for improvement in processing these data" [BLC2:09:00371]

(9) "I thought you could give him an insightful perspective of how the risk experience has helped you to move to your current role. If you can swing it, I think it would be great if Mike could sit with you one day, and you could explain to him your job, [...]" [EEDdoc\#275-Filename: sent-mail_bass-e.nsf]

Unlike hedges, boosters reinforce the writer's stand-point. Adverbs such as 'actually', 'certainly', 'obviously', 'indeed', or 'never'; adverbial expressions such as 'in fact', 'no doubt', 'of course', 'to be clear', serve to emphasize the writer's confidence. The function of boosters can also be achieved using verb phrases with 'believe', 'find', 'know', 'think', in order to reassure the reader of the strength of the writer's argument. It is in the balance between hedges and boosters that the writer shows "commitment to text content and respect for readers." (Hyland, 2005, p. 53). Boosters were found to be widely used in CEOs' letters "to build up a confident image in order to win confidence from shareholders and potential investors" (Hyland, 1998b; Huang \& Rose, 2018 , p. 180). However, despite the length of the corpora, the selection of adverbial and verb expressions used as boosters in these corpora is relatively limited and is proportionately lower than the number of hedges. One exception is the verb 'think', seen in the clauses 'I think/I thought', which on closer scrutiny was found to be used both as a booster and a hedge. Table 6, which reports the number of occurrences, shows that the most commonly used adverbs are 'always' in the BLC, and 'really' in the EED (in hundreds in both corpora).

Table 6. Boosters serve to emphasize certainty or close dialogue

\begin{tabular}{lllll}
\hline BOOSTERS & EED & \multicolumn{3}{l}{ BLC } \\
\cline { 2 - 5 } & $\#$ & $\%$ & $\#$ & $\%$ \\
\hline always & 153 & 0.01 & 457 & 0.04 \\
believe/s/ed & 282 & 0.03 & 399 & 0.04 \\
never & 254 & 0.02 & 178 & 0.02 \\
really & 415 & 0.04 & 285 & 0.02 \\
Sure & 413 & 0.04 & 673 & 0.06 \\
I think/I thought & 1671 & 0.17 & 1094 & 0.11 \\
\hline
\end{tabular}

The letter sample (10) shows how the clause 'I think' can have the function of a booster, rather that of a hedge. Here, 'I think' strengthens the statement that follows, which contains an attitude marker ('it is appropriate to') and the other booster 'should not', to express confidence and exclude any possible alternative viewpoint. Besides, the use of a self-mention marker in combination with the booster contributes to creating a credible image of authority. Similarly, in the letter extract (11), confidence in presenting a stand-point is achieved by using combinations of the self-mention 'we' and the booster 'believe' to introduce a criticism, and again with the self-mention 'we' and another booster in 'we are sure' to offer a solution.

The email in extract (12) has a slight change of tone, where the bank official reassures the client by combining evidence with a direct address to the interlocutor, using the engagement marker 'you' and the booster 'really'. 
By appealing to emotion, the writer is averting any potential preoccupations on the part of the client.

The three examples that follow show evidence of how metadiscourse contributes to discourse as a means of persuasion. In all samples, boosters, in combination with other interactional categories of metadiscourse (self-mentions, engagement markers and attitude markers), serve to build professional credibility (Ethos). Additionally, in (10) and (11) they appeal to reason (Logos), while in (12) the booster used serves to create affective appeal (Pathos).

(10) "I think it is appropriate to point out that these ratings should not be taken lightly." [BLC2:02:02453]

(11) "We believe that poor marketing is the main reason for the old-fashioned image people have of your products, and there is a lack of brand identification which we are sure can be overcome with a well-presented advertising campaign.” [BLC2:22:01919]

(12) "Right now you can use the entire amount in your money market for your muni bond portfolio. After the treasury comes due on Jan 31, 2002, you will have another $\$ 750.000$. You really don't have to worry about your margin requirements because you still get $80 \%$ of the value of your municipals credited towards marginable securities." [EEDdoc\#177-Filename: sent-items_allenp.txt]

\section{Pedagogical Implications in the EBC Class}

Business communication studies have shown that learning English for business communication is more than just knowing the semantics of lexico-grammar. Students have to learn to recognize the conventions their community members use to negotiate meaning in professional text writing. Besides, they also need to understand why members of a specific business or professional discourse community communicate the way they do (Bhatia \& Bremmer, 2014, pp. 3-4). Research has shown that introducing metadiscourse to students of English as a second/foreign language contributes to improving their writing and speaking skills. Furthermore, it helps to understand the notions of register and tone, to refine ethical sensibility as well as the ability to assess information accuracy and validity. In particular, in the EBC class, the study of metadiscourse is key to understanding the relationship of language and rhetoric to business communication. The introduction to the concrete use of metadiscourse as a powerful tool for persuasion can help EBC students to learn to use the communication skills needed to achieve business-oriented goals in their professional community. Yet, the question of how to best make metadiscourse salient to students is paramount to this pedagogical purpose.

Doing research into and analysis of business-text writing has revealed that the production of actual real-world practitioners often differs from the models found in business English textbooks (Evans, 2012, p. 204). Thus, even though they may be dated, real texts can be useful resources for teaching metadiscourse in the EBC class, as the corpora analysed here demonstrates. Indeed, they provide a great variety of real texts which can create opportunities for comparison and contrast with more recent texts. Furthermore, they allow the selection of smaller subsets of texts to be used for pedagogical purposes. Indeed, business-letter and email writing and their various functional use, as well as culture-bound stylistic differences, are commonly present in the syllabi of business English courses.

The BLC corpus, for instance, includes business letters, memorandums and other business-related documents written in American and British contexts to fulfil a large array of purposes, going from inquiries to complaints, from apologies to claims, from negotiations to order processing, from business proposals to seasonal greetings. An example of how to exploit the material available for this study is the following. The analysis of case studies is a learner-motivating activity type presently offered in the most recent textbook editions. If this is assigned as a problem-solving task, students would have to analyse the given situational case and act to bring to a solution the task. In this inductive process, one of the fruitful steps, based on the case at hand, would be the analysis of a subset of business letters with a corpus manager. Given appropriate guidance, students can find out by themselves what rhetorical strategies are used to fulfil the functional purpose at hand, and be introduced in this way to metadiscourse categories and functions. Exposure to real functional use of metadiscourse and to the expediency of using it for its own specific rhetorical purpose, favours acquisition and experiential learning.

Another way to exploit the texts available in the corpora analysed is to have EBC students compare and contrast meaningful samples of business letters and emails, so as to gain a sensibility on how to build credibility appeals, and affective appeals with metadiscourse commentaries, before actually using them themselves. Especially in the case of email writing, the study of the contextual situation is vital to understand the communicative choices made or to be made. Accordingly, the development of inductive scaffolding activities would be most appropriate for these purposes. As a first step of the task, students could be given email samples to study in terms of language choices and purpose(s). The analysis of metadiscourse strategies can help to have them make 
hypotheses on the context where the email was most possibly produced. In a second step, they could be asked to react to the email in an appropriate manner, as if they were the intended readers. Again, meaningful samples coming for the EEC could be provided for them to consider. In particular, the choice should fall on text samples where metadiscourse occurrences were found to be statistically relevant. Although this study has revealed a modest quantitative presence of Hyland's (2005) interactional features, awareness of how and where self-mention and engagement markers are used (the most present features of metadiscourse in the corpora studied) remains critical and worth using in the EBC class.

Once students have identified and classified conventions and discourse strategies used by their profession to achieve the desired impact on their community members, they need to use these skills in order to consolidate them. Activities of text manipulation, where they are supposed to find alternative metadiscourse commentaries to accomplish the same rhetorical functions in a variety of possible contexts, would achieve this objective. From a learning perspective, this type of task activates productive skills, and helps students to classify vocabulary and strategies in relation to collocation and contexts of use. The key issue for this type of task is to provide texts in context; in other words, to find case studies where a text satisfies this didactic purpose rather than merely presenting discrete, sentence-level exercises or templates to fill in. Finally, adherence to the underlying principle of learning by doing, and engaging students in real-world tasks and in problem-solving situations, helps students to learn to use metadiscourse in order to be successful communicators and to achieve professionally-oriented goals.

\section{Conclusions}

This study has provided partial results for on-going research designed to evaluate the rhetorical presence of metadiscourse in two corpora, one of corporate emails and the other of business letters, written in English (mostly by native speakers) in the years when internal and external business communication was adjusting to digitalization. In the first place, the survey carried out here has confirmed the difficulties involved in doing research on metadiscourse with large corpora. Moreover, the findings presented only refer to what Hyland (2005) classified as interactional metadiscourse, and they reveal that the occurrence of interactional features was statistically less significant than expected. Yet, they confirm previous results which ascribed a central role to metadiscourse in building persuasion in business discourse, when it is used.

The quantitative analysis has shown that self-mentions and engagement markers have the highest incidence rate in both corpora, even though they are higher in the letters than in the emails corpus, as expected. Similarly, while the presence of hedges and boosters is almost negligible in both corpora, it was slightly higher in the business letters than in the emails. Unexpectedly, the occurrence of attitude markers is statistically almost insignificant in both corpora, though especially in the email corpus.

The interactional metadiscourse commentaries which were found to have some statistical relevance were almost the same in both corpora, albeit to a different degree in emails and letters. Given that they belong to different text genres, this confirms the idea that corporate emails and business letters were produced by writers and for readers who belong to the same professional community. The metadiscourse features analysed serve to create rational appeal to readers by helping them to interpret the message. They also build credibility appeals, which are especially important in business communication; lastly, they engage with the readers' expectations and attitudes through affective appeals. The use of metadiscourse for rhetorical purposes should find a stable place in the Business English class, however this is a vast topic which could just be touched at this time, and that deserves a deeper study on its own right.

Furthermore, in view of the increasing reliance on email for workplace communication in the past few decades and in the foreseeable future, it would be worthwhile investigating and comparing more recent email and business letter corpora, to diachronically evaluate metadiscourse variation within the same text genres. Finally, further research in corporate communication is needed especially after the Covid 19 pandemic has forced businesses to move online en masse.

\section{References}

Abdollahzadeh, E. (2011). Poring over the findings: Interpersonal authorial engagement in applied linguistics papers. Journal of Pragmatics, 43, 288-297. https://doi.org/10.1016/j.pragma.2010.07.019

Ädel, A. (2006). Metadiscourse in L1 and L2 English. Amsterdam/Philadelphia: John Benjamins Pbl. Company. https://doi.org/10.1075/scl.24

Ädel, A. (2010). Just to give you kind of a map of where we are going: A taxonomy of metadiscourse in spoken and written academic English. Nordic Journal of English Studies, 9(2), 69-97. 
https://doi.org/10.35360/njes.218

Ädel, A. (2012). 'What I want you to remember is...': Audience orientation in monologic academic discourse. English Text Construction, 5(1), 101-127. https://doi.org/10.1075/etc.5.1.06ade

Ädel, A., \& Mauranen A. (2010). Metadiscourse, diverse and divided perspectives. Nordic Journal of English Studies, 9(2), 1-11. https://doi.org/10.35360/njes.215

Ágnes, M. G. (2012). Are you with me? A metadiscursive analysis of interactive strategies in College students' course presentations. International Journal of English Studies, 12(1), 55-78. https://doi.org/10.6018/ijes.12.1.118281

Ahour, T., \& Saeideh, E. M. (2014). The effect of metadiscourse instruction on Iranian EFL learners' speaking ability. English Language Teaching, 7(19), 69-75. https://doi.org/10.5539/elt.v7n10p69

Al Mudhaffari, M., Hussin, S., \& Abdullah, I. H. (2020). Interactional strategies in L2 writing: An exploration of hedging and boosting strategies in applied linguistics research articles. International Journal of Arabic-English Studies, 20(1), 171-186. https://doi.org/10.33806/ijaes2000.20.1.9

Amiryousefi, M., \& Rasekh, A. E. (2010). Metadiscourse: Definitions, issues and its implications for English teachers. English Language Teaching, 3(4), 159-167. https://doi.org/10.5539/elt.v3n4p159

Attarn, A. (2014). Study of metadiscourse in ESP articles: a comparison of English articles written by Iranian and English native speakers. International Journal of Learning, Teaching and Educational Research, 5(1), 63-71.

Bhatia, V. K., \& Bremner, S. (2012). English for business communication. Language Teaching, 45(4), 410-445. https://doi.org/10.1017/S0261444812000171

Biber, D. (2006). Stance in spoken and written university register. Journal of English for Academic Purposes, 5, 97-116. https://doi.org/10.1016/j.jeap.2006.05.001

Carrió-Pastor, M. L. (2019). Authorial engagement in business emails. A cross-cultural analysis of attitude and engagement markers. In C. S. Guinda (Ed.), Engagement in Professional Genres (pp. 47-66). Amsterdam/Filadelphia: John Benjamin Pbl. https://doi.org/10.1075/pbns.301.03car

Carrió-Pastor, M. L., \& Muñiz Calderón, R. (2015). A contrastive analysis of metadiscourse features in business e-mails written by non-native speakers of English. Procedia, Social and Behavioral Sciences, 173, 214-221. https://doi.org/10.1016/j.sbspro.2015.02.055

Chang, L. (2015). The influence of task-based metadiscourse instruction on university students' writing quality. In M. Wang (Ed.), Proceedings of the 2015 International Conference on Management Engineering and Management Innovation (pp. 240-245). Atlantis Press. https://doi.org/10.2991/icmemi-15.2015.42

Crawford Camiciottoli, B. (2003). Metadiscourse and ESP reading comprehension: An exploratory study. Reading in a Foreign Language, 15, 28-44.

Crismore, A. (1989). Talking with readers. Metadiscourse as rhetorical act. New York: Peter Lang.

Crismore, A. (1990). Metadiscourse and discourse processes: Interactions and issues. Discourse Processes, 13, 191-205. https://doi.org/10.1080/01638539009544753

Crismore, A., Markkanen R., \& Steffensen, M. S. (1993). Metadiscourse in Persuasive Writing. A study of texts written by American and Finnish university students. Written Communication, 10, 39-71. https://doi.org/10.1177/0741088393010001002

Crismore, A., \& Vande Kopple, W. J. (1997). Hedges and readers: Effects on attitudes and learning. In R. Markkanen \& H. Schröder (Eds.), Hedging and discourse: Approaches to the analysis of a pragmatic phenomenon in academic texts (pp. 83-114). Berlin: Walter de Gruyter. https://doi.org/10.1515/9783110807332.83

Ehrenreich, S. (2010). English as Business Lingua Franca in German multinational corporation. Journal of Business Communication, 47, 408-431. https://doi.org/10.1177/0021943610377303

Estaji, M., \& Vafaeimehr, R. (2015). A comparative analysis of interactional metadiscourse markers in the introduction and conclusion sections of mechanical and electrical engineering research papers. Iranian Journal of Language Teaching Research, 3(1), 37-56.

Evans, S. (2012). Designing email tasks for the Business English classroom: Implications for a study of Hong Kong's key industries. English for Specific Purposes, 31, 202-212. 
https://doi.org/10.1016/j.esp.2012.03.001

Fatalaki, J. A., Amini E., \& Mirzaee, M. (2014). The role of explicit interactive metadiscourse markers' instruction in Iranian EAP learners' reading comprehension. East European Journal of Psycholinguistics, $1(2), 14-24$.

Fuentes Olivera, P. A., Velasco Sacristán, M., Arribas Baño, A., \& Samaniego Fernández, E. (2001). Persuasion and advertising English: Metadiscourse in slogans and headlines. Journal of Pragmatics, 33, 1291-1307. https://doi.org/10.1016/S0378-2166(01)80026-6

Giordano, M., \& Marongiu, M. A. (2020). 'And as I said at the beginning, this is a journey in which we are embarking': Metadiscourse as a rhetorical strategy in online teaching methodology courses. In L. D'Angelo, S. Consonni \& P. Anesa (Eds.), Digital Communication and Metadiscourse: Changing Perspectives in Academic Genres (CERLIS Series vol. 9, pp. 131-162). Bergamo: CELSB.

Harris, Z. S. (1959). The transformational model of language structure. Anthropological Linguistics, 1(1), $27-29$.

Hewitt, P. L. (2006). Electronic mail and internal communication. A three-factor model. Corporate Communication, 11, 78-92. https://doi.org/10.1108/13563280610643570

Hong, H., \& Cao, F. (2014). Interactional metadiscourse in young EFL learner writing. Journal of Corpus Linguistics, 9(2), 201-224. https://doi.org/10.1075/ijcl.19.2.03hon

Hu, G., \& Cao, F. (2011). Hedging and boosting in abstracts of applied linguistics articles: A comparative study of English- and Chinese-medium journals. Journal of Pragmatics, 43, 2795-2809. https://doi.org/10.1016/j.pragma.2011.04.007

Hu, C., Wong, A., Cheah, H., \& Philip, W. (2009). Patterns of email use by teachers and implications: A Singapore experience. Computers \& Education, 53, 623-631. https://doi.org/10.1016/j.compedu.2009.04.007

Huang, Y., \& Rose, K. (2018). You, our shareholders: Metadiscourse in CEO letters from Chinese and western banks. Text \& Talk, 38(2), 167-190. https://doi.org/10.1515/text-2017-0041

Hyland, K. (1998a). Hedging in scientific research articles. Amsterdam: John Benjamin. https://doi.org/10.1075/pbns.54

Hyland, K. (1998b). Exploring corporate rhetoric: Metadiscourse in the CEO's letter. The Journal of Business Communication, 35(2), 224-244. https://doi.org/10.1177/002194369803500203

Hyland, K. (2000). Disciplinary discourses: Social interactions in academic writing. London: Longman.

Hyland, K. (2001). Humble servants of the discipline? Self-mention in research article. English for Specific Purposes, 20(3), 207-226. https://doi.org/10.1016/S0889-4906(00)00012-0

Hyland, K. (2004). Disciplinary interactions: Metadiscourse in L2 postgraduate writing. Journal of Second Language Writing, 13, 133-151. https://doi.org/10.1016/j.jslw.2004.02.001

Hyland, K. (2005, 2019). Metadiscourse. Exploring interaction in writing. London/New York: Bloomsbury Plc.

Hyland, K. (2017). Metadiscourse: What is it and where is it going? Journal of Pragmatics, 113, 16-29. https://doi.org/10.1016/j.pragma.2017.03.007

Hyland, K., \& Jiang, F. K. (2018). "In this paper we suggest": Changing patterns of disciplinary metadiscourse. English for Specific Purposes, 51, 18-30. https://doi.org/10.1016/j.esp.2018.02.001

Hyland, K., \& Tse, P. (2004). Metadiscourse in academic writing: A reappraisal. Applied Linguistics, 25(2), 156-177. https://doi.org/10.1093/applin/25.2.156

Jensen, A. (2009). Discourse strategies in professional e-mail negotiation: A case study. English for Specific Purposes, 28, 4-18. https://doi.org/10.1016/j.esp.2008.10.002

Kankaaranta, A. (2006). Hej Seppo, could you pls comment on this! - Internal email communication in lingua franca English in a multinational company. Business Communication Quarterly, 69, 216-225. https://doi.org/10.1177/108056990606900215

Lee, J. J., \& Subtirelu, N. C. (2015). Metadiscourse in the classroom: A comparative analysis of EAP lessons and university lectures. English for Specific Purposes, 37, 52-62. https://doi.org/10.1016/j.esp.2014.06.005

Mauranen, A. (1993). Contrastive ESP rhetoric: Metatext in Finnish-English economic texts. English for Specific Purposes, 12, 3-22. https://doi.org/10.1016/0889-4906(93)90024-I 
Reitbauer, M. (2001). Are you with me? Talking to readers in academic discourse: An empirical investigation into using metadiscourse as a means of improving reading comprehension. Arbeiten aus Anglistik und Amerikanistik, 26, 199-211.

Ryoo, M. (2005). Metadiscourse in computer-mediated communication in a culturally diverse group. Discourse and Cognition, 12(1), 21-41.

Salas, M. D. (2015). Reflexive metadiscourse in research articles in Spanish: Variation across three disciplines (linguistics, economics and medicine). Journal of Pragmatics, 77, 20-40. https://doi.org/10.1016/j.pragma.2014.12.006

Tavakoli, M., Dabaghi, A., \& Khorvash, Z. (2010). The effect of metadiscourse awareness on L2 reading comprehension: A case of Iranian EFL learners. English Language Teaching, 3(1), 92-102. https://doi.org/10.5539/elt.v3n1p92

Vande Kopple, W. J. (1985). Some exploratory discourse on metadiscourse. College Composition and Communication, 36(1), 82-93. https://doi.org/10.2307/357609

Vande Kopple, W. J. (2002). Metadiscourse, discourse, and issues in composition and rhetoric. In E. Barton \& G. Stygall (Eds.), Discourse studies in composition (pp. 91-113). Cresskill, NJ: Hampton Press.

Vande Kopple, W. J. (2012). The importance of studying metadiscourse. Applied Research in English, 1(2), $37-44$.

Vashegani Farahani, M., \& Abdallah Mohemmed, A. I. (2018). Metadiscourse in academic vs. non-academic writing: A comparative corpus-driven Inquiry. Bulletin of the Transilvania University of Braşov (Series 4: Philology and Cultural Studies), 11(60-1), 145-166.

Vashegani Farahani, M., \& Pahlevansadegh, V. (2018). Teaching metadiscourse features and IELTS writing performance of Iranian EFL learners. A learner corpus-based perspective. Journal of Applied Research in Higher Education, 11(3), 538-558. https://doi.org/10.1108/JARHE-10-2018-0222

Xiaoqin, L. (2017). Exploring the rhetorical use of interactional metadiscourse: A comparison of letters to shareholders of American and Chinese financial companies. English Language Teaching, 10(7), 232-241. https://doi.org/10.5539/elt.v10n7p232

Zhang, M. (2016). A multidimensional analysis of metadiscourse markers across written registers. Discourse Studies, 18(2), 204-222. https://doi.org/10.1177/1461445615623907

Zhang, M., Sun, W., Peng, H., Gan, Q., \& Yu, B. (2017). A multidimensional analysis of metadiscourse markers across spoken registers. Journal of Pragmatics, 117, 106-118. https://doi.org/10.1016/j.pragma.2017.06.004

\section{Notes}

Note 1. see Appendix: Metadiscourse items investigated, in Hyland, 2005, pp. 218-224.

\section{Copyrights}

Copyright for this article is retained by the author, with first publication rights granted to the journal.

This is an open-access article distributed under the terms and conditions of the Creative Commons Attribution license (http://creativecommons.org/licenses/by/4.0/). 